\title{
Organizational Citizenship Behavior among staff Nurses at Dikirnis General Hospital
}

\author{
IZeinab EidMohammed r ‘Asmaa Mustafa Abel-ghanir‘Abeer Mohamed Zakaria \\ B.Sc.in Nursing, Lecturer of Nursing Administration-Faculty of Nursing, Mansoura University, \\ Professor of Nursing Administration, Mansoura University
}

\begin{abstract}
Back ground: In healthcare organization, nurses are considered as a backbone of its success as their performance and behaviors are key determinants for good performance.Today, health care organizations need efficient leaders and policy makers to devote attention to create and cultivate the dimensions and principles of Organizational Citizenship Behavior (OCB). Aim: The study aims to assess the organizational citizenship behavior among staff nurses at Dikirnis General Hospital. Method: a descriptive research design was utilized, the study was conducted on 252 staff nurses working at Dikirnis General Hospital. Data was collected by usingorganizational citizenship behavior questionnaire. Results: the results of this study indicated that more than half of the staff nurses had high perception of organizational citizenship behavior. Conclusion:The nurses' perception of organizational citizenship behavior was at high level for more than half of the studied staff nurses. Direct manager should focus on how they deal with their staff nurses because nurses' perception of that treatment would affect the presence of organizational citizenship behaviorRecommendation: Organize periodically meeting with supervisors and their staff nurses to discuss their problems, needs and involve them in solving it. Encourage staff nurses to give suggestions for work development.
\end{abstract}

Key words: Organizational Citizenship Behavior, staff nurse 


\section{Introduction}

In each organization's human resource portfolio, skilled and dedicated workers have always been a valuable resource because their experiences and commitment will dramatically influence the overall performance of the organization (Đorđević et al, 2019). Without the contributions of the human resources, organizations cannot accomplish its goals. The main players in translating these goals are human resources in the form of performances, attitudes and interactions (Scott \& Davis, 2016).

Nurses are the largest group working in health care organizations.Goodnurseare not only tho se who arewilling to fulfill their duties an dresponsibilitiesbut can also showan attitude beyond their responsibilitiesas a mean of sympathy to colleagues and organization. Attitude displayedw illingly bynurseswithout coercion and not linkedto the scheme of salaryor $\mathrm{c}$ ompensation known as OCB (Hamsani et al, 2019). Organizational communication and functioning can be achieved by having a higher number of nurses with OCBso the biggest intellectual capital for an organization is its nurses with OCB employed to achieve organization objectives (Yıldız, 2016).

OCB appears when more efforts than prescribed are performed by nurses in order to accomplish for organization's performance and assisting their colleagues to attain the work. Support should be provided by the head nurses to the nurses during work performance since there is longer time needed more essential work assignments. If the nurses are satisfied with their work conditions, the nurses will do their best and will give the favor to get better results and tend to fulfill OCB (Veličkovska, 2017). five $\begin{gathered}\text { Dimensions of OCB identifiedare } \\ \text { dimensions, including }\end{gathered}$ conscientiousness, altruism, civic virtue, sportsmanship, and courtesy (Bolat, Seymen, 2009).Conscientiousness shows that a specific person is organized, accountable, and hardworking(Mohammad \&Tahere, 2018). Altruism is linked voluntarily aid to specific people in the workplace and associated with a task or organizational problem (Fani,Danaeed\&Zakani, 2013). Civic Virtue refers to the accountability of coworkers to participate in work life; such participation can be like participating in meetings not mandated by the organization but preserve developments in the organization(Mohammad\&Tahere, 2018). Sportsmanship generally involves enduring inappropriate working conditions and situations causing troubles without showing any dissatisfaction.Courtesy reflects the quality of individuals' behavior with their colleagues, supervisors and audience.

(Castro, Carmen, Armarioetal, 2004).

In assessing organizational efficiency and contributing to organizational effectiveness OCB has an important role. For organizations as well as for workers OCB is important. Providing better services are provided by nurses as a result of OCB. OCB also reduce employee turnover, increase employee commitment to the organization, enhance job satisfaction and economized organizational resources (Organ 2018).

Significance of study:

Retaining staff nurses with OCB behaviors increase quality of work, patient satisfaction, positive involvement of in the hospital governance, taking precautions to avoid problems, showing 
selflessness behavior and showing devotion to high standards of the work completion. OCB has a great effect with organizational variables such as Job satisfaction, Job commitment and Turnover intentions which were held accountable for employees (Huak\&Pivi, 2015)so, the aim of the study is to assess the organizational citizenship behavior among staff nurses

\section{Aim of the study:}

\section{The study aimed to:}

Assesstheorganizational itizenship behavior among staff nurses at Dikirnis General Hospital.

\section{Research Questions:}

RQ1:Is there an organizational citizenship behavior among staff nurses at Dikirnis General Hospital?

\section{Subject and Methods}

Study design:

A descriptive design was used in to accomplish the aim of the present study in assessing the organizational citizenship behavior among staff nurses. It is used to describe characteristics of a population or phenomenon being studied.

\section{Study setting:}

The study was conducted at Dikirnis General Hospital that provide health services to seven centers in Dakahlia governorate is located in the North Eastern region of Delta, Egypt. It consists of four building. It provides inpatient care to approximately 912 patient and Outpatient care to approximately 3000 patient monthly.

\section{Study subjects \& technique:}

The subjects of the present study included all available staff nurses who have experience at least one year and willing to participate in the study at time of data collection in the previously mentioned study setting over the period of two months from June 2020 to August 2020. Their total study numbers were
(252) staff nurses classified as following (81) staff nurses have diploma degree, (82) staff nurses have technical degree and (89) staff nurses have bachelor degree.

Tools of data collection:

Tool for data collection were used to collect data for this study namely: Organizational Citizenship Behavior Questionnaire.

It consists of two parts:

Part I: This part aimed to collect socio-demographic characteristics of study subjects includes: age, gender, marital status, qualifications in nursing, years of experience.

Part II: Organizational Citizenship Behavior Questionnaire

This tool was developed by Organ (1990) and modified by Abo Tayh (2012).It aims to assess organizational citizenship behavior among staff nurses. It comprises of 20 items categorized into Altruism (5items), courtesy(4items),sportsmanship(3items), civic (5items) and conscientiousness (3 items). Scoring system:

Each statement response will be considered based on five-point Liker scale from 1(Strongly Disagree), 2 (Disagree), 3 (Neutral), 4 (Agree), 5 (Strongly Agree). The total score was categorized as either low $(<50 \%$ of the total score), moderate $(50 \%-75 \%$ of the total score) and high ( $>75 \%$ of the total score).

Validity of the study tools:

Data collection tool translated by researcher into Arabic and tested for its content validity and relevance via a paneloffive experts from nursing administration department from Faculty of Nursing Mansoura University who reviewed the tools for clarity, relevancy, applicability, comprehensiveness, 
'Zeinab EidMohammed et. al.

understanding and ease for implementation and according to their opinions simple modifications were applied.

Reliability of the study tool:

The reliability of Organizational Citizenship Behavior Questionnaire measured by cronbach's alpha was good (.91) indicating high reliability.

\section{Ethical consideration:}

The researcher obtained ethical approval from the research ethics committee of the faculty of Nursing, Mansoura University. A formal permission was obtained from administrator of Dikirnis General Hospital to carry out the study. Explanation of the aim and the nature of the study were performed by the researcher to all staff nurses included in the study. Participation in research was voluntary, each staff nurse was informed about their rights to refuse or participate or withdraw from the study at any time without giving reasons. The study maneuvers not entail any harmful effect on participants. Confidentiality of the collected data was maintained, results were used as component of the necessary research as well as for future publication and education.

\section{Research process:}

The process was carried out through two phases; preparatory and operating phases. Preparatory phase included; reviewing literature, translating tools and pilot study while the operating phase included; data collection and data analysis.

\section{Preparatory phase:}

It included reviewing the local and international relevant literature and theoretical knowledge about the various aspect of the study using articles, books, journals related to the study aim to obtain required information for translating, validating and preparing tools for collecting data.

Pilot study:

A pilot study for data collection tools was carried out on $10 \%$ (28) staff nurses that randomly selected and were excluded from the total sample to evaluate the clarity and applicability of the tool to appraise the clarity, feasibility and applicability of the tools and necessary modifications were done based on their responses.. It helped in identifying potential obstacles and problems that may be encountered during the period of data collection. It has also served to estimate the time needed to fill the study tools. It took about 15-20 minutes to fill in the study tools.

\section{Operating phase:}

\section{Data collection phase}

The researcher met the subjects to explain the study purpose and ask for their participation. The researcher met the respondents either individually or groups during morning and afternoon shifts to distribute the data collection sheets to the respondents in their work units and present during filling to clarify any ambiguity and answer any questions. Data was collected two days per week. The researcher checked each filling questionnaire and ensuring its completeness. Data collection phase was carried out in the period from the beginning of June to the end of August 2020.

Data analysis phase

The collected data were organized, tabulated and statistically analyzed using SPSS software (Statistical Package for the Social Sciences, version 22, SPSS Inc. Chicago, IL, USA). Categorical variables were represented as frequency and percentage. Continuous variables were represented as mean, and standard deviation. 
Organizational Citizenship Behavior among etc...

Independent t-test was used to test the difference between two mean of continuous variables. ANOVA test used to test the difference between more than two mean of continuous variables. Chisquare test was conducted to test the association between two categorical variables. Pearson correlation coefficient test was conducted to test the association between two continuous variables. Statistically significant was considered as (p-value $\leq 0.01 \& 0.05$ ).

Results:

Table (1): Studied nurses' socio demographic characteristics $(n=252)$

\begin{tabular}{|c|c|c|}
\hline Variables & $\mathrm{n}$ & $\%$ \\
\hline Age years: & \multirow[t]{2}{*}{65} & \multirow[t]{2}{*}{25.8} \\
\hline - $\quad 20-30$ & & \\
\hline - $31-40$ & 159 & 63.1 \\
\hline - $\quad>40$ & 28 & 11.1 \\
\hline \multicolumn{3}{|l|}{ Gender } \\
\hline - $\quad$ Male & 5 & 2.0 \\
\hline - $\quad$ Female & 247 & 98.0 \\
\hline \multicolumn{3}{|l|}{ Marital status } \\
\hline - $\quad$ Single & 18 & 7.1 \\
\hline - $\quad$ Married & 216 & 85.7 \\
\hline - $\quad$ Divorced & 12 & 4.8 \\
\hline - $\quad$ Widowed & 6 & 2.4 \\
\hline \multicolumn{3}{|l|}{ Level of education } \\
\hline - $\quad$ Diploma degree & 81 & 32.1 \\
\hline - $\quad$ Technical degree & 82 & 32.5 \\
\hline - $\quad$ bachelor degree & 89 & 35.3 \\
\hline \multicolumn{3}{|l|}{ Experience years: } \\
\hline - $\quad<10$ & 79 & 31.3 \\
\hline - $10-20$ & 143 & 56.7 \\
\hline - $>20$ & 30 & 11.9 \\
\hline
\end{tabular}

Table (1) : shows that more than half(63.1\%) of staff nurses had age ranged between (30-40), more than $(98 \%)$ were females, majority of the studied nurses(85.7) were married, more than one third $(35.3 \%)$ had bachelor degree and more than one half $(56.7 \%)$ had years of experiences ranged between (10-20)years.

Table (2): Mean scores of nurses' organizational citizenship behavior $(n=252)$

\begin{tabular}{|l|c|c|c|}
\hline \multicolumn{1}{|c|}{ Organizational citizenship behavior } & No of items & Min - Max & Mean \pm SD \\
\hline Altruism & 5 & $9.0-25.0$ & $20.25 \pm 2.51$ \\
\hline Courtesy & 4 & $8.0-20.0$ & $16.08 \pm 1.89$ \\
\hline Sportsmanship & 3 & $5.0-15.0$ & $11.17 \pm 2.12$ \\
\hline Civic virtue & 5 & $11.0-25.0$ & $18.94 \pm 2.79$ \\
\hline Conscientiousness & 3 & $3.0-15.0$ & $9.84 \pm 2.92$ \\
\hline Total organizational citizenship behavior & 20 & $51.0-99.0$ & $76.31 \pm 9.16$ \\
\hline \\
Table (2): shows that the highest were
\end{tabular}

mean score was altruism(20.25 \pm 2.51$)$ 
'Zeinab EidMohammed et. al.

\begin{tabular}{lll}
\hline $\begin{array}{l}\text { conscientiousness }(9.84 \pm 2.92) \\
\text { sportsmanship }(11.17 \pm 2.12) .\end{array}$ & and $\quad \begin{array}{l}\text { OCB: Organizational Citizenship } \\
\text { Behavior }\end{array}$
\end{tabular}

Figure (1) Mean scores of nurses' organizational citizenship behavior $(n=252)$

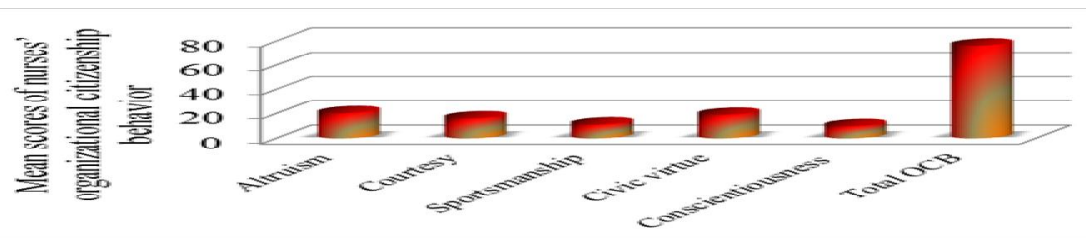

Figure (1): shows that the mean score conscientiousness was $(9.84 \pm 2.92)$ and for altruism was $(20.25 \pm 2.51)$ and for sportsmanship was $(11.17 \pm 2.12)$.

Table (3): Levels of nurses' organizational citizenship behavior $(n=252)$

\begin{tabular}{|c|c|c|c|}
\hline Organizational citizenship behavior levels & Score & n & $\%$ \\
\hline Low $(<50 \%)$ & $20-49$ & 0 & 0.0 \\
\hline Moderate $(50 \%-75 \%)$ & $50-75$ & 104 & 41.3 \\
\hline High $(>75 \%)$ & $76-100$ & 148 & 58.7 \\
\hline
\end{tabular}

Table (3): demonstrate that $(58.7 \%)$ of high level, $(41.3 \%)$ had moderate level the studied nurses perceived of organizational citizenship behavior.

organizational citizenship behavior at

Figure (2): Levels of nurses' organizational citizenship behavior $(n=252)$

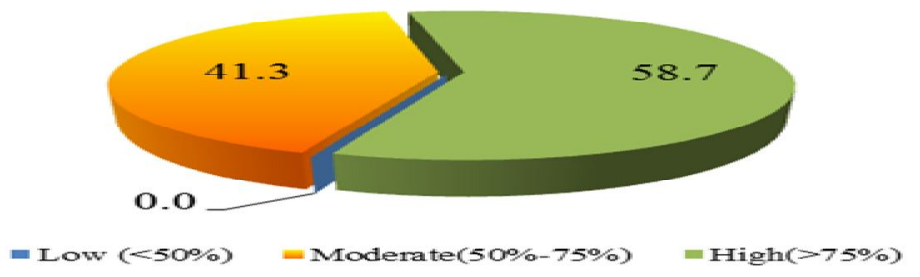

\section{Discussion:}

Nurses do their best and exert high level of effort when they feel that they are supported by organizations that care about their well-being and value their contributions, which encourages them to engage in OCB. Individual behaviors that are generally unnoticed but which collectively shape organizational orientationcomprises theorganizational citizenship behavior Organizational citizenship behavior refers to the willingness of employees to go beyond the formal specifications of work roles(Mahmoud\&Ibrahim, 2016). Hence, thecurrent study aimed to assess the OCB among staff nurses
Regarding to the variable investigated in the present study which was OCB. The findings of the present study showed that, more than half of the studied nurses hada high level of OCB perception. This may be due to presence of supporting nurses' actions to other nurses, sense of commitment and belonging, utilizing all their time to do their best for work, respecting the regulations and policies of the hospital spirit of teamwork with their colleagues and nurses who expect to keep their jobs because they work for long times. The finding in agree with research conductedbyMohamed (2019)who 
Organizational Citizenship Behavior among etc...

mentioned that, more than half of the nurses surveyed had positive OCB.

On contrast with the study findings were the study of Khalifa \& Awad (2018) who found that the nurses viewed the mean score percentage of OCB was moderate. This may be due to the presence of behavioral support among the nurses. Another study conducted by Quraan \& Kasawneh, (2017)stated that, actions of OCB and its dimensions (altruism, courtesy, sportsmanship, civic virtue and conscientiousness) had achieved low levels of significance from the point of view of respondents. Moreover, Demirkiran et .al.,(2016) mentioned that, OCB perception of the participants was moderate.

In conclusion the present study finding revealed that, mean score of nurses' perception of altruism was the highest mean score of OCB while the lowest mean score were with the Conscientiousness and sportsmanship dimensions. This may be due to that nurses like to cooperate with their colleagues to carry out the tasks but in other times, the workload is increased, so nurses can't endure additional work, and keep away from meetings, making suggestions and avoid volunteering in problem solving.

This finding in agreement with Mohamed, (2019) who conducted a study about influence of OJ on OCB among staff nurses, found that, the highest percentage was with the domain of the altruism the lowest score were with the sportsmanship and conscientiousness domain. While, this finding is in disagreement with Khaled (2012) who mentioned thatconscience as coming first, followed by friendliness, altruism, while, sportsmanship and civilized conduct came last.

\section{Conclusion}

From the present study, it was concluded that:

The nurses' perception of organizational citizenship behavior was at high level for more than half of the studied staff nurses. Direct manager should focus on how they deal with their staff nurses because nurses' perception of that treatment would affect the presence of organizational citizenship behavior.

\section{Recommendations}

Based on the results of this study, it was recommended that:

\section{For Hospital administration:}

- Provide more flexible atmosphere at hospital.

- Establish a committee that discuss nursing staff problems.

For Nurse Managers:

- Encourage working in groups.

- Encourage staff nurses to suggestions for work development.

For Nurses:

- Involve themselves in continuous learning programs to increase their knowledge and achieve quality of work and patient satisfaction.

- Encourage nurses to have a sense of creativity and involve themselves in problem solving by providing a good ideas to solve.

\section{References:}

Abo Tayh, B (2012). The Impact Of Organizational Justice On Organizational Citizenship Behavior In Governmental Ministries Centre In Jordan Islamic University For Economic And Administrative Studies 20(2):145-186 
Bolat , O.I., Bolat, T \&Seymen, O.A.(2009).GuclendiriciliderDavr anislariVeorgutselVatandaslikDav ranisiSosyaMubadeleKuramindan HareketlelIncelemesiBalikesir University

SosyalBilimlerEnstitusuDergis Cilt12 Sayi 21 ss.215-239.

Castro., Carmen, B., Armario., Enrique ., Ruiz., \&David's .(2004) " The influence of employee OCB on customer loyalty ", international journal of Service industry management, Vol.15 No.1, pp 276-282.

Dermirkiran, M., Taskaya, S., \&Dinc, M., (2016). A study on the relationship between organizational justice and organizational citizenship behavior in hospitals. International Journal of Business Management and Economic Research, 7(2), 547554.

Đorđević et al. (2019). The influence of organizational justice on corporate performances MajaIvanović-

ĐukićVinkoLepojević Sandra Milanović DOI: 10.5937/StraMan1903014D pp. 014-023

Fani, A.A., DanaeedFard, H., \&Zakani, Sh. (2013). The Effect of Organizational Justice on OCB and Organizational Justice: Explaining the Role of a Healthy Personality in Organizational Management Research in Iran, Volume 17, Issue 1, pp. 148-133
Hamsani, H., Valeriani, D.,\&Zukhri, N.(2019). Work Status, Satisfaction and Organizational Citizenship Behavior. International review of management and marketing 9(3), 1-8. https://doi.org/10.32479/irmm.783 $\underline{8}$

Huak, M., \&Pivi, F. (2015). The impact of organizational citizenship behavior on employee's job satisfaction, commitment and turnover intention in dining restaurants Malaysia. International Journal Accounting,Business, and Management, 1(1), 1-17.

Khalifa, S.M.A., \&awad, N.H.A. (2018). The Relationship between Organizational Justice and Citizenship Behavior As Perceived By Medical-Surgical Care Nurses. PP 31-37. IOSR Journal of Nursing and Health Science (IOSR-JNHS) e- ISSN: 2320 1959.p- ISSN: 2320-1940 Volume 7, Issue 4 Ver. IX (Jul.-Aug. 2018), www.iosrjournals.org

Khaled, M.K. \&Alhyasat. (2012): The role of Islamic work ethics in developing organizational citizenship behavior at the Jordanian Press Foundations", Journal of Islamic Marketing,

Mahmoud, A.S., \& Ibrahim, S.A.E. (2016). Factors in Nurses' Organizational Citizenship Behavior. IOSR Journal of Nursing and Health Science (IOSR-JNHS) e-ISSN: 2320 1959.p- ISSN: 2320-1940 Volume 5, Issue 2 Ver. VI (Mar. - Apr. 2016), PP 22-28 www.iosrjournals.org DOI: 10.9790/1959-0502062228 www.iosrjournals.org 22 | Page . 
Mohamed, R, M.(2019). Influence of Organizational Justice on Organizational Citizenship Behavior among Nurses. Egyptian journal of health care 10(2):264276. DOI: $10.21608 /$ ejhc. 46257.

Mohammad, S, H., \&Tahere, S, K. (2018). the impact of workplace spirituality on organizational citizenship behavior (OCB) with the mediating role of organizational commitment in nurses of Rasht Hospitals, Iran. J Adv Pharm Edu Res (S2):30-36.

Organ, D. W. (2018). Organizational Citizenship Behavior: Recent Trends and Developments. Annual Review of Organizational Psychology and Organizational Behavior, 80, 295-306.

Organ, D. (1990). Organizational citizenship behavior: the good soldier syndrome.lexington,MA.
Quraan, A., \&Khasawneh, H. (2017). Impact of organizational justice on organizational citizenship behavior: Case study at Jordan national electric power company. European Journal of Business and Management, 9(15), 215-229.

Scott, R\& Davis, G. (2016). Organizations and Organizing: Rational, Natural and Open Systems Perspectives. New York.

Veličkovska, I. (2017).Organisational Citizenship Behaviour-Definition, Determinants and effects. Engineering Management, 3(1), 40-51. Retrieved from https://menadzment.tfbor.bg.ac.rs/ english/wp-content/uploads/ sites/2/2017/02/3_1_40-51.pdf

Yıldı, S. M. (2016).İşyerinde mobbing

davranışlarınınsporvefizikseletkinl ikişletmeleriçalışanlarınınörgütsel vatandaşlıkdavranışınaetkisi.

DokuzEylülSosyalBilimlerEnstitüs üDergisi, 18 (1), 165-180. 